politic context. Even though the meaning of the material has been known by the community, the actors also develop discourses in certain situations. Hence my criticism of the traditionalists angle because tends not to discuss how the communities conducts discourse to build a positive image in the midst of the negative stigma that plagues them. This paper rectifies the over-emphasis on the role the structural factors, like semiotic and fixed message (meanings) in local communities to explain revival and resistance of them. In this paper, I develop an argument that the social politic context has effect and explain how the practice of the discursive of them. Furthermore, the paper explains on how people retain the religious practices that their Belief with the support materials.

I outline my argument with case Penghayat Sapta Darma communities with their narratives in their oral discussing or coversation in Jakarta. The women of the community called Warga wear Kebaya in some momentum in Jakarta. The white Kebaya has a deep meaning that motivates them to behave of their Kebaya meaning. I found this motivation of discussion with them in their events. They wear the white Kebaya and share their narrative about the purity symbols.

The phenomena for the white Kebaya of Warga looks unique because Penghayat usually identically with the black-Kebaya. In Cilacap, the black-Kebaya related to the shadow of human and eternal and noble symbol. In Jakarta, I tend to see that other religious groups use white in their clothes and accessories. Example, Majelis Ta'lim in Indonesia. The Habib and his congregation used white robes and white turban (Jati, 2015) when pray, the Asy-Syahadatain wear a white shirt (Rohman, 2011) and the LDF-FPI (Da'wah Front Institute of Defender Front of Islam or FPI) wear are long white shirt with white hajj or Imamah caps (Hakim, 2014).

Jakarta is the central city of Indonesia. It is bordered by several other areas, open, and not isolated. As part of the citizens of Jakarta, the Warga a have members with various professions, such as security guards, nurses, hotel employees, traders, teachers, lecturers, and state apparatus. Interaction with other groups is possible in Jakarta. This condition allows them in meeting and discussing or conversation other people. Some of the them are active in internal meetings, between organizations, and the meeting are facilitated by the state. Although the rights of them have been accommodated by the state in several cases, they still encounter problems due to the ritual practices, as reported and recounted by them in the case of the attack of the Islamic
Defenders Forum (FPI) to their worship place in Yogyakarta in 2008.

The purpose of this paper is to explain the dynamics of religious relations that exist in Jakarta, narratives to build positive meanings of religious groups, and how the material is used in denominational narratives. This paper shows how symbols function to support materials. The functions are a motivational, strengthen the community identity, and an expression to develop moral and religious commitment. With the symbols in the material, the community then creates narratives for the purpose of building a positive image. The role of narrative is also to negate of the alienation positions of the community, protest marginality and demand for equality. In practice of religious interaction, they build discourses through the use of their Kebaya symbol. With a sacred conception, the community strengthens the solidarity of its groups who are considered marginalized.

The study of cultural material pragmatism is still limited of the abundance of similar studies of Penghayat, such as mysticism (Mulder, 2011), Javanese philosophy or outlook, individual motivation of the spiritual practice (Sutarto, 2006), syncretism practice (Irwanti, 2019) and their diverse (Hamudy \& Rifki, 2020:48), their stigmas and construction (Azis, 2017; Ikhsan, 2017), the political resistance (Qodim, 2017; Aryono, 2018), history (Pratama, 2017), and landscape (Khoirnafiya, 2019). The study gap of previous literature because the absence of discussion of the role of symbols in material (Kebaya) in discourse of Warga. The gaps are then filled with this paper, how the narrative built by them amidst their negative stigma. Their narrative emphasizes how the white Kebaya worn is in accordance with the character of their pure identity, behaves cleanly, and is covered with calm. The study of religious identity constructed by Warga has relevance to idea that identity as something inherent in the community with its boundaries. The boundary is not only symbolic interaction and other social relations, but also the area of identity symbolically constructed as a reflection of the search for differences or changes. Although they are multi-identity, the symbols play to maintain identity boundaries. Ethnicity have a multi-layered structure but ethnic identities are quite resistant to change (Cohen, 2019).

There is subjectivity from identity owners but also there is effort to dismantle identity crisis and the religious basis can be reduced conflict identity become integration identity as well as the ethnicity role to construct the cultural rights of the communities (Cojanu, 2014). In a religious-based of social movement, individuals are blocked from defining individual identity towards group identity, demanding strict 
adaptation of traditions, symbols and values to the interests of the group. There are main symbols and vice versa others symbols that threatens solidarity are rejected or replaced, reinterpreted, and reused at a later time. In this study, the identity bases on Sapta Darma that the revelations received from men of Java (Javanese).

This paper show that the identity of the citizens is plural but not float. The affirmation in group norm is their significant in Cohen idea about the saliency of ethnic identity in context, called "retribalization" (affirmation of his return) that re-definition ethnic identity in response to external threats. They have the ability to deconstruct customs, values, myths, and ceremonies from their cultural traditions to articulate their active political organizations where interacts with outsiders (Cohen, 1978). Recognizing ethnicity include all related behavior and all the material of collectives. Material traces may be found e.g. in symbols. In this study, ethnicity is used as a political resource and an understanding of morality (Antweiler, 2015;Munasinghe, 2018; Ross, 2008).

Thus, this paper contributes to the study of a more dynamic religious group, by considering material in support of community discourse. The functioning of these materials shows that it is not only history factors (Segara, 2019: p. $151)$, only which influences the practice of discourse, but also the cultural material role in the practice of discourse. The relevance of the material in this study shows a different perspective on the idea that allegations of fetishism for artifacts (Miller, 1998). Because material in not absence because in practice of religious group, there is the improve materials process, dematerialization and rematerialization (Kao, 2020).

\section{B. METHOD}

$\mathrm{T}$ his ethnographic study interprets the related archives and literature, interviews of Warga, collects stories of their experiences and memories, understands the knowledge or rationality of them, and analyzing the narratives in conversation by them.

\section{RESULT AND DISCUSSION}

\section{Identity, Myth and Narratives in} Sacred Space

$\mathrm{S}$ ince President Suharto's speech on August 18, 1978, Penghayat Kepercayaan terhadap Tuhan Yang
Maha Esa.have been linked to terms of belief in Supreme God as a culture is not religion. They are a person who acknowledges and believes in the values of the belief in God Almighty. Although it has been standardized, the term of Penghayat is not single. The discussion result of informant, there are the dedication of Faith, Devoted of Faith Community, Faithful People, Native Faith Follower, believer on one Almighty God, Adherent, spiritual religious and local wisdom, a Belief in Almighty God, and Indigenous religion.

They belief their local religion is origin come from the Javanese ancestors, long before official religion - they often called import religion - in Java. The Belief also developed and gained many followers. However, the informant told me that there was no problem he used the word religion-at that time, but around 1963 the Sapta Darma Religion was replaced with Sapta Darma Spiritual (Kerohanian Sapta Darma or KSD). Then, Sapta Darma became a Belief in God organization be Persada (Persatuan Sapta Darma). Persada was inventoried in 1980 by the Directorate General of Culture, the Ministry of Education and Culture with Inventory Number I. 135 / F.3 / N.1.1 / 1980. Some of them regretted the change because it was in their narrative that religion related words, $A$ is the same as the origin of man, $\mathrm{Ga}$ is the same as Gama (Kama or holy water), and $\mathrm{Ma}$ is the same as virtual or the light of God. By them, the Sapta Darma will be the role model of the world community.

In their narrative, the religion is not interpreted in a limited way. The religion is not just the fulfillment of the elements such as prophet-hood, scripture, and international recognition. They responded that the rules only made humans, the rules of religion should not be determined by humans including the government and Java is ethno-national.

Like a Javanese woman, the female of Warga generally roll her hair (Gelung) with Kebaya, but they use the white Kebaya. Meanwhile, the male usually uses batik and Beskap by tucking a Javanese dagger in their fingers and completing it with lket or Blangkon. There is a lot of information that diversity of Warga but in their narrative in conversation signaled that a tendency to uniform the diversity of Persada's identity with Kejawen (Java Spiritual) as Warga value orientation or philosophy. 
Their narratives also related of Javanese meanings, that Javanese means someone who understands or does not leave Java, not conflict with any interests and establishes harmony with anyone. Javanese in its philosophy of being in various arenas is a symbol of the cohesiveness of the them. Also, related to the Private symbol of Sapta Darma, the embodiment of heroism, authority seven and moment, and the language to communicate with Hyang Maha Kuasa through prostration and prostration songs. The certain symbols in religion was very emphasized because it was able to make humans immediately feel close to an extraordinary power (Geertz, 1973; 2013).

The narrative of the Warga is also related to the white symbol that is believed through the sacred myth of receiving teaching revelations of Harjosopoero (Mr. Sri Gutomo) myth on 12 July 1954. Then written by Panuntun and disseminated to his followers until now. Its related revelation to draw in to mori (white cloth-textile), Sapta Darma word and moral Javanese with Javanese alphabet The Personal Symbol.

The informant said that they believe the Revelation myth. They said that white has a noble meaning, purity and peace and the absence of color, another kind of emptiness. This symbol is a human concept as Hyang Maha Suci related the origin of human can be seen from the rectangular shape of the rhombus. The white indicates that the human origin of goods is holy or clean, both inside and outside. Therefore, people should always try to return to their pure/clean state; acting to nobleness or physical and spiritual purity and and return to their origin. They said that the white symbol differs from some other colors in Javanese knowledge, for example Black circles illustrate that humans have Ankara (arousal lust), their forms in dirty words spoken by mouth so that humans must say and act well; the red circle illustrates that humans have anger that arises due to sound stimulation by the ears so that the sound is not good not felt; and the yellow circle describes craving because of the influence of the sense of sight from the eye.

The White depicts of the circle is different of the black, red, and yellow as the bad category. This is different from the white meaning in a circle that describes a sacred action even though it is closer to yellow (craving) but has a sense of smell from the nose which is stimulated by good smells, holy and clean instead of refusing to be dirty. If humans want to have vigilance (clairvoyance) then the eyes, ears, and mouth are guided to the nose character. Thus, humans can match (bring together actions) with their origin is chastity. Likewise, the white on the circle covered by the Semar image illustrates the hole in the human crown as the tenth-hole. Likewise, the white in the image of Semar (the image of nobility light) can relate to Hyang Maha Kuasa (Allah). By blending togethers the feeling in the crown until realizing white light, then it can be God's face.

In Warga-women narrative, this Personal Symbol as Hyang Maha Suci is the inspiration and motivation for them to wear white Kebaya. They want to shine and glow like the white of light, while Kebaya for them is related to the Java identity. The Sapta Darma symbol describes the origin and content of humans, which must be understood and cultivated by humans in order to achieve nobility according to Wewarah Pitu (seven clues). The white of the Kebaya contains hidden meanings than dirty stigma and the narrative that the white color of their teachings as not mystical but sacred.

Like the white Swarajin cloth white soaks up corruption and sin and White (Sveta) also means merriment (Jha S., 2016: 7). The mythical provides an explanation that color as a symbol has meaning contained in it which is transmitted orally. This study provides an explanation that the teachings about the human being as the Holy One continue to be transmitted by the myth. This is use material like the physical manuscript and the religious images, what was regarded material was mediated by semiotic ideology example the healing entailed material practices (studio). That new believers had to take to continue to articulate their break with local religion (Kao, 2020:9-11).

The minority like Warga who filled with trauma and crisis, the experience of togetherness in daily life becomes an essential element. The personal or groups try to manage cultural cohesion, they are creative, related to "hidden transcript " which represents a criticism of power is dominant as its expression is different from the open / frontal form. They try to continue narrating the equality of the beliefs of their ancestral religion with other religions. Not only that, a critical insight into external 
pressures borne by religious groups of this kind can be revealed in their art performances.

\section{The Purity Claim, Pride and Retain Belief}

I repeatedly asked about the white Kebaya worn by the female. From several informants, the answer was similar that they wanted white to glow as white as light as the teachings of Wewarah Pitu. As personal symbol meaning, the white meaning contains good moral values so that the white color appears in some attributes of the problem. There are male informants said that white means cleanliness and kindness. I question several times about their white studio cloth, their Kebaya in a white (wedding) confirmation process which is also worn by women during the process of burial of bodies or funerals. White means mutmainnah which benefits from purity and negative shamanism.

I have not yet obtained an explanation from the Warga about the origin of this word of superstition. In Arabic language mutmainnah related to al-nafs al-mutmainnah (the serene nafs) in 'state of ultimate peace, the highest stage of psychospiritual development (AbuRaiya, 2012). White (Abiath) is the primary symbolism with the positive assumption that if something is white, it is not stained and therefore clean (A.Hasan, 2011).

Such claims of purity appear universal when we read some similar references. White is black opposite in binary category. Although it is comparable in comparison, it appears that White is more favored than black by some communities. Like Charles Daniel Redmond dissertation "Those without Sin" shows the political and social supremacy from white Christianity (Redmond, 2017). The pure white color has dominated the public face as a remarkable cultural heritage and as the importance of prestige (Port, 2007). Likewise for Indians who believe that Kshatriyas in the color of Padma (white lotus), Vaisyas in slightly light color and Sudras dark (Jha S. , 2016).

The specialty of the white color of a person's skin is white features. The white box contains positive goals, and vice versa the black box contains negative goals reveal morality versus immorality. Like Fox's study that whites in a marginal position of belonging, their inextricability from land and power continues to mark them as privileged persons with counternationalist ethics of patrimony and wealth accumulation (R.Fox, 2012). This is the strategies of stigma management (Kowal, 2011).

The relevance White shows a cultural pattern of the rule of purity. She saw a difference between white magic and black magic. Their rationality is the white spirit is not angry but happy to be slaughtered Danger. From some community rituals, this purity pattern is applied in life especially in renewal efforts to eliminate pollution (Douglas, 2001). Monochromatic "black" and "white" are the basic color terms used in any human language. Where more than two color terms exist, these two are universally with terms for other colors following in a consistent sequence across languages. White related the Levantine Paleolithic, has its own powerful semantic: in bones, skulls, and skeletons however white paints when derived from a mixture of water and clayor chalk, would probably not have survived archeologically as well as ochre, manganese, or charcoal (Hovers, llani, BarYosef, \& Vandermeersch., 2003)

In the argument of this paper, white is interpreted by Warga and then made a binder of solidarity but in their efforts to carry out their stigma which is heretical or even non-religious. White also contains ideologies that show purity, kindness, and generosity. White is shown in the connotation of cleanliness which has left a bad thing. I believe that the ideology of the positive meaning of white is transmitted by the generation of Warga and can be accessed by audiences who want to know them. Warga's performance shows that civilization was built to minimize the darkness of animism and mysticism in the practice of spirituality directed at them. White appearance is an expression of their teaching beliefs about humans as Hyang Maha Suci.

White like the sun shines signifies human respect that is part of God. In Warga meeting, they tried to wear white Kebaya. For women, almost every moment of their meeting tries to wear a white Kebaya. This was shown when several the women who did not wear white Kebaya then shyly walked into the meeting room. The woman whispered and told some of her friends that she did not wear white Kebaya for various reasons. Her reasons are her white Kebaya washed or sewn because of greatness. 
Meanwhile, some other women are ready to bring some white Kebaya. They have to borrow or give away for free.

The Warga-woman gave two Kebaya and happy. She not yet known white Kebaya meaning was brought and worn. But some the women (as Warga inborn) explained the white meaning. It may not be exactly the same but this the meaning also contained in the Sanggar cloth (pedestal) which is worn for their prostration. In certain momentum, they are in the prostration of daily prostration.

There are many meanings of someone's wear Kebaya. However, their white Kebaya means purity. Talks of Kebaya color often satire with other groups that hinder their worship, use violence to destroy the Persada studio (prostration), and improper behavior of religious people. Their expressions appear more often when they feel confident. They are talking to is believed to be someone who wants to understand them. They said that other groups need to clarify the misunderstanding of the practice of their 'religion'.

\section{Discourse in Social Relation and Cultural Context}

Warga believes in the Personal Symbol so they wear white Kebaya. The Belief not only in private spaces, but also public spaces. They convey this white theme that in line with the white shine like the sun shines. There is a white symbol meaning, as portrays the holy lust that gives rise to good character and attitude. The analysis of discourse space expected to be able to build or shape them not only reflect something far from them. Some of the underlying discourses are social identity or 'subject position', social relations, and systems of knowledge and trust. The discourse existences use various aspects, including intellectual analysis and social practice.

I try to interpret the results conversation with Warga in their daily practices and responding to cases that happened to them, such as the case of the worship place destruction in Yogyakarta. The term sujud is their problem which often leads as a heretical group. They say that prostration is the result of the revelation of the founders of their ancestors. So, the term sujud prostration was rejected by other groups because they did not understand their teachings. They said that the prostration was not the property of Islam.

In their discourse, there is masking or elimination of agencies through the construction of passive sentences in the worship place destruction. In some meeting, they did not mention the agency but stated the studio has been damaged by Islamic groups. In others situation, they say "this is not inappropriate for someone who claims to be religious, right, Ms". They say "aren't the religion teaches goodness and peace and harming. They said that they on average have experienced injustice.

True religious teachings of them are often their claim. For examples the statement: we are nrimo (accept), but God does not sleep, in real many of the worship place destroyers who died unnaturally, some committed suicide, some fell from sewers. Whether or not this is true, such statements appear in the Jakarta, the religion legitimizes very effectively because it connects the construction of reality with sacredness. The sequence of events presented or such narratives reveal that religion in the questioned narrative takes place on a 'cosmic' scale, including their own 'reality other than everyday experience.

Religious legitimacy is discursive construction. Although religious can cause social conflict religion becomes social cohesion. In the integration perspective, religion is a prominent identity that can control society. Religion offers a set of structures of beliefs that internalize moral tension and use them to guide life choices and moral commitments. The white Kebaya shows the emotional reaction of the wearer, both political emotions and their religious emotions. Kebaya revealed the issue of religious morality. The white Kebaya functions as a portrait of a person who is not only represented in ideas but has significant meaning in building mental representations of Warga who are often stigmatized by the occult, heretical, and non-religious. The shared meaning based on the teachings of faith then operates in the actions and performance of its citizens to effectively shape the identity. In the context of the meaning of the sacred text allows multi-vocal but then guide by leader.

Religious emotion is sought to be built through various possible means including a chastity discourse which should not debate the contents of the sacred text. This kind of orthodoxy apparently does not only occur in a number of other faith-based groups, but also them. Although there are several practices that have changed from practices that have existed in the past, they always build narratives that their elders do consider it does not conflict with the teaching values of their beliefs. In their perspective, emotionally they respect their ancestors as a moral obligation for their ancestral heritage but the text is useful for sustainability in the changing times they live. Changes that exist are not as opposed to the sacred text while still basing the essence of the content of the text. 
In their narrative that Kebaya is not the only their representation but Indonesia identity with positive character and the traditional values. For them, Kebaya is expected not to be replaced with other clothing including wearing robes that are rife now. They said that the robe as a representation of Islam (both women and men) comes from Arab culture which is now frightening because of the issue of radicalism. In addition, the niqab as a complementary attribute is seen as a culture of female closeness and human inequality.

The text can be assimilated, contradictory, ironically echoed, etc. The use of interdiscursive also emphasizes the implicit aspiration of discourse in addition to explicit textual references. I got their narratives when I present at the studio, chatting in cars or buses, or joking in the kitchen even a discussion that struck my Muslim identity on a studio cloth. Their small voices are often the same as those of a leader but not infrequently the different ones are conveyed by whispering in my ear.

The religious issue, the study shows cloth produced and then as a body cover (clothing) that contributes as a marker for various purposes, including traditional ceremonial media worn. Autonomy of clothing combines with the values of existing traditions, but sometimes it is influenced by the conflicts that exist in the community. This material can be barrier between self (self) with other people (other) or between individuals with their groups (community) and between groups in society. Thus, the Kebaya as social visualization is structured by certain rules or norms in the realm of togetherness and not alienation.

\section{CONCLUSION}

$\mathrm{T}$ his paper has sought to provide a framework to explain the material, meaning and the narratives in social interactions or relations. By focusing on narratives of material (Kebaya), this study has effort to the material (Kebaya clothing) related social relations and cultural context. The materials not only strengthen religious group solidarity but also help or communicate identity for efforts to consolidate social and cultural contexts by sharing the meanings contained in the material. This paper has showed the importance of dynamic of structure through community narratives of religious group in their transformation. I should state clearly that the meanings of material have effect in community knowledge but in case Warga in Jakarta, the narratives of the social units or institutions organized relate to landscape, geography, history and mobility. Producing the narrative pursued these goals in a contestation field. The cognitive efforts are not separated in the practice of spiritual activities, but rationality encourages them to carry out discourses for group survival in their political and social context. The white Kebaya as an instrument to retain or resist their Belief.

\section{E. ACKNOWLEDGMENT}

would like to express my gratitude to Mr. Semiarto Aji Purwanto, my teacher, in University of Indonesia, and to the anonymous informants for their help and suggestions.

\section{REFERENCES}

A.Hasan, A. (2011). How Colors are Semantically Construed in the Arabic and English Culture: A Comparative study. English Language Teaching Vol. 4, No. 3; September , 206-213.

Abu-Raiya, H. (2012). Towards a systematic Qura'nic theory of personality. Mental Health, Religion \& Culture, 15:3, 217-233.

Antweiler, C. (2015). Ethnicity from an anthropological perspective. Dalam A. K. Becke, Ethnicity as a Political Resource. Germany: University of Cologne Forum.

Arroisi, J. (2015). Aliran Kepercayaan dan Kebatinan: Membaca Tradisi dan Budaya Sinkretis Masyarakat Jawa. AL-Hikmah: Jurnal Studi Agama-Agama/Vol. 1, No. 1. 
Aryono. ((2018)). Pergulatan Aliran Kepercayaan Dalam Panggung Politik Indonesia, 1950an-2010an: Romo Semono Sastrodihardjo dan Aliran Kapribaden. . Jurnal Sejarah Citra Lekha, Vol. 3 , No. 1, 58-68.

Azis, F. (2017). Konstruksi Sosial Penghayat Kerohanian Sapta Dharma (KSD) terhadap Ajaran KSD dalam Kehidupan Sosial (Studi di Sanggar Agung Candi Busana Sapta Dharma Kecamatan Pare Kabupaten Kediri)'. Surabaya: Skripsi Departemen Sosiologi Universitas Airlangga.

Basit, A. (2016). Strategi Perlawanan Kelompok Penghayat Kapribaden Terhadap Diskriminasi Agama (Studi Kasus Di Dusun Kalianyar Desa Ngunggahan Kecamatan Bandung Kabupaten Tulungagung). Tulungagung: Skripsi Jurusan Filsafat Agama Fakultas Ushuluddin, Adab Dan Dakwah Institut Agam silam (IAIN) Tulungagung.

Cohen, N. L.-E. (2019). Ethnic origin and identity in the Jewish population of Israel. Journal of Ethnic and Migration Studies, 45:11, 2118-2137.

Cohen, R. (1978). Ethnicity: Problem and Focus in Anthropology. Source: Annual Review of Anthropology, Vol. 7, 379-403.

Cojanu, D. ( 2014 ). Ethnicity as Social Fact and Symbolic Construction. Procedia - Social and Behavioral Sciences 149, $217-221$.

Douglas, M. (2001). Purity and Danger: An Analysis of Concepts of Pollution and Taboo, imprint of the Taylor \& Francis Group . London and New York:: Routledge.

Geertz, C. (1973). The Interpretation of Cultures, Selected Essays. New York: Basic Books, Inc., Puhlishers .

Geertz, C. (2013). Agama Jawa: Abangan, Santri, Priyayi dalam Kebudayaan Jawa, judul asli The Religion of Java, diterjemehakan oleh Aswab Mahasin \& Bur Rasuanto. Depok: Komunitas Bambu.

Hakim, A. R. (2014). Pencitraan Laskar Pembela Islam FPI dalam Mentransformasikan Nilai-Nilai Islam di Tengah Masyarakat (Studi Kasus Program Pembinaan Keagamaan Lembaga Dakwah Front. Jakarta: Skripsi, Fakultas IImu dan Komunikasi, UIN Syarif Hidayatullah Jakarta, .

Hamudy, M. I., \& Rifki, M. S. (2020). Civil Rights Of The Believers Of Unofficial Religions (Penghayat Kepercayaan) In Pekalongan District,. Jurnal Antropologi: Isu-Isu Sosial Budaya - Vol. 22 No. 01 (June 2020), 48-59.

Hartami, K. (2010). Memahami Kepercayaan terhadap Tuhan YME dan Organisasi Penghayat Kepercayaan terhadap Tuhan YME untuk Menyongsong Indonesia menjadi Oboring Jagad. Dalam D. K. YME, Anggoro Kasih: Sarana Transformasi Nilai Budaya Spiritual (hal. 125-136). Jakarta: Direktorat Kepercayaan terhadap Tuhan YME, Ditjenbud, Kemdikbud.

Hovers, E., Ilani, S., BarYosef, O., \& Vandermeersch., B. ( 2003). An Early Case of Color Symbolism: Ochre Use by Modern Humans in Qafzeh Cave. Current Anthropology, Vol. 44, No. 4 (August/October) , 491-522.

Ikhsan, M. A. (2017) ). Perbandingan Konsep Ketuhanan Kristen dengan Ketuhanan Sapta Dharma. Jakarta: Skripsi Jurusan Studi Agama-Agama UNI Syarif Hidayatullah Jakarta.

Indrianti, P. (2013). Gaya Busana Kerja Muslimah Indonesia dalam Perspektif Fungsi dan Syariah Islam. el Harakah Vol 15 No. 2, 150-168.

Irwanti, N. (2019). Sinkretisme Islam Jawa dalam Pernikahan Adat Jawa (Studi Kasus di Desa Karangnangka Kecamatan Kedungbanteng Kabupaten Banyumas). Purwokerto: Program Studi Sejarah Peradaban Islam, Fakultas Ushuluddin, Adan dan Humaniora, Institut Agama Islam Negeri.

Jati, W. R. (2015). Islam Populer sebagai Pencarian Identitas Muslim Kelas Menengah Indonesia', Teosofi Islam. Jurnal Tasawuf dan Pemikiran Islam Volume 5 Nomor 1, (2015), 159.

Jenkins, R. (1994). Rethinking ethnicity: Identity, categorization and power. Ethnic and Racial Studies, 17:2, 197-223. .

Jenkins, R. (1996). Ethnicity etcetera: Social anthropological points of view. Ethnic and Racial Studies, 19:4, 807-822.

Jenkins, R. (2008). 'The Ambiguity Of Europe: 'Identity crisis' or 'situation normal'? European Societies, 153-176. 
Jha, S. (2016). 'From Sacred to Commodity and Beyond: Color and Values in India. Journal of Human Values, vol. 22, 1-13.

Kao, C.-y. (2020). Materiality in the absence of the church: Practising protestantism during China's Cultural Revolution. History and Anthropology, 1-21.

Karyaningsih, E. W. (2015). Faktor-Faktor yang Mempengaruhi Pemilihan Kebaya Pada Ibu-lbu dan Remaja Putri. Jurnal KELUARGA Vol 1 No 1 Februari , 7-13.

Khoirnafiya, S. (2019.). "Nature as Culture of Penghayat: The Landscape, Reaction, and Movement of Penghayat in Cilacap. ETNOSIA: Jurnal Etnografi Indonesia. 4(2), 127 - 143.

Kowal, E. (2011). The Stigma of White Privilage . Cultural Studies, 25:3, 313-333.

Miller, D. (1998). Introduction, Why some things matter. Dalam D. M. (ed), Material cultures Why some things matter (hal. 1-21). London.: UCL Press.

Munasinghe, V. ( 2018). Ethnicity in Anthropology . The International Encyclopedia of Anthropology, $1-12$.

Niels Mulder. (2011). The Crux Is the Skin: Reflections on Southeast Asian Personhood. Journal of Current Southeast Asian Affairs, 95-116.

Port, M. v. (2007). Bahian white: The dispersion of candomblé imagery in the public sphere of Bahia. Material Religion, 3:2, 242-274.

Pratama, B. (2017). Kajian Historis Aliran Kepercayaan Sapta Darma Di Kecamatan Ponggok Kabupaten Blitar (Historical Studies Cult Sapta Darma in the District of Blitar District Ponggok. Artikel Skripsi Universitas Nusantara PGRI Kediri. Program Studi Pendidi.

Qodim, H. (2017). Strategi Bertahan Agama Djawa Sunda (ADS) Cigugur'. KALAM, Volume 11, Nomor 2, 329-364.

R.Fox, G. (2012). Race, Power and Polemic: Whiteness in the Anthropology of Africa. . Totem: the University of Western Ontario Journal of Anthropology, Volume 20, Issue 1, 9-24.

Redmond, C. D. (2017). Those without Sin: Voices of Color on White Protestant Christianity in Nineteenth-Century American Literature. ProQuest Dissertations Publishing.

Rohman, A. (2011). Persepsi Kelompok Syahadatain Terhadap Nilai- Nilai Toleransi di Kabupaten Banyumas. Jurnal "Analisa" Volume XVIII, No. 02, 280-282.

Ross, R. (2008). Clothing: A Global History or, The imperialism New Clothes. Cambridge: Polity Press.

Segara, I. N. (2019). Ngempon: The Role-Sharing Strategy of Hindus and Muslims In Bhur Bwah Swah Temple, Karangasem, Bali. Jurnal Antropologi: Isu-Isu Sosial Budaya-Vol.21no.0 2(December 2019). , 150-158.

Suciati. ( 2019 ). Ethics and Aesthetic Appearance of Kebaya Indonesia. Advances in Social Science, Education and Humanities Research, volume 406, 305-308.

Suliyati, T. (2019). Rumah Bugis sebagai Bentuk Pemertahanan Budaya. Masyarakat Bugis di Desa Kemojan Karimunjawa. Endogami: Jurnal IImiah Kajian Antropologi Vol. 2 No. 2 : Juni, 203211.

Sutarto, A. (2006). Becoming a True Javanese: A Javanese View of Attempts at Javanisation. Indonesian and the Malay World, 34-39.

Syafwan. (2016). Kebertahanan Rumah Gadang dan Perubahan Sosial di Wilayah Budaya Alam Surambi Sungai Pagu, Kabupaten Solok Selatan. Humanus, Vol. XV No. 1, March, 105-119.

Tarigan, R. (2019). Membaca Makna Tradisionalitas Pada Arsitektur Rumah Tradisional. Jurnal Arsitektur KOMPOSISI, Volume 12, Nomor 3, April .

Wuryani, S. (2013). Lurik Dan Fungsinya Di Masa Lalu. Ornament. Vo.10. Vol 1. Januari , 81-100. 